\title{
A Simple Trade Model with an Optimal Exchange Rate Motivated by Discussion of a Renminbi Float
}

\author{
Hui Huang, ${ }^{1}$ Yiming Wang ${ }^{2}$, John Whalley ${ }^{3}$, Shunming Zhang ${ }^{4}$ \\ ${ }^{1}$ Faculty of Business Administration, The University of Regina, Regina, Canada \\ ${ }^{2}$ Department of Finance, School of Economics, Peking University, Beijing, China \\ ${ }^{3}$ Department of Economics, Social Science Centre, The University of Western Ontario, London, Canada \\ ${ }^{4}$ China Financial Policy Research Center, School of Finance, Renmin University of China, Beijing, China \\ Email: hui.huang@uregina.ca, wymecon@126.com, jwhalley@uwo.ca, szhang@ruc.edu.cn,shunming.zhang@gmail.com
}

Received March 22, 2012; revised April 25, 2012; accepted May 8, 2012

\begin{abstract}
We present a model of combined inter-spatial and inter-temporal trade between countries in which there is a fixed exchange rate with a surrender requirement for foreign exchange generated by exports. The model incorporates intertemporal intermediation services, which may or may not be liberlized across countries. We use numerical simulation methods to explore the properties of the model, since it has no closed form solution. In this model, when services remain unliberalized there is an optimal trade intervention, even in the small open price taking economy case. Given monetary policy and an endogenously determined premium value on foreign exchange, an optimal setting of the exchange rate can provide the optimal trade intervention. We suggest this model may have loose relevance for the current situation in China where services remain unliberalized and tariff rates are bound in the WTO and a free Renminbi float is under discussion.
\end{abstract}

Keywords: Fixed Exchange Rate; Foreign Exchange Premium; Services; JEL Classification: F00; F02; F31; F32

\section{Introduction}

This paper takes as its point of departure macro literature on the choice of exchange rate regime. While the choice between a fixed and flexible exchange rate regime has long been argued and debated in classical monetarist terms (that a fixed exchange rate implies accommodating monetary policy, and monetary policy determines the floating rate) as in Friedman's [1] discussion, there is little literature that suggests that there may exist an optimal exchange rate which dominates a free float ${ }^{1}$.

We use a model of combined inter-spatial and intertemporal trade between countries in which there is a fixed exchange rate accompanied by a surrender requirement for foreign exchange generated by exporters. Huang, Whalley and Zhang [4] earlier analyzed the merits of trade liberalization in financial services using a related approach both with no treatment of the exchange rate require. In their model, in the presence of tariffs on inter-spatial trade free trade in services, even for a small open price taking economy, may not be welfare improving, and free trade in goods may not be Pareto optimal if services trade remains unliberalized.

\footnotetext{
"This work is supported form National Natural Science Foundation of China (NSFC Grant: 70825003) and National Social Science Foundation of China (SSFC Grant: 07AJL002).
}

In the model presented here, under either auctioning of foreign exchange received by the central bank among importers, or some non auctioned foreign exchange allocation mechanism with domestic trading in foreign exchange, there will be a premium value on foreign exchange which is endogenously determined and operates akin to a tariff on imports. In simple models where income effects among consumers are assumed away, domestic monetary policy in such a model is non neutral, while trade liberalization (a tariff reduction) merely changes the premium value on foreign exchange, leaving trade unchanged. Since monetary policy is non-neutral, when services remain unliberalized there is an optimal trade intervention, even in the small economy case. This occurs because given monetary

\footnotetext{
${ }^{1}$ Such a contention is relevant to current policy debate in China, since with an optimal exchange rate a freely floating rate may be welfare worsening. China has long maintained a fixed exchange rate with tight regulation of domestic banks, and strict limits on entry to the Chinese market for foreign financial institutions. In past, this has reflected a desire for macro stability, but the Chinese banking system also differs sharply from those in OECD countries with small but growing personal banking, and state owned banks acting in part as mechanisms for recapitalizing loss making state owned enterprises. Thus, much of what is at state in the debate on financial liberalization in China and the choice of exchange rate regime is the form and operation of the Chinese banking system and how this would change with a freely floating fully convertible Renminbi and this goes well beyond the discussion here (see Zhang and Pan [2] and Chang and Shao [3]).
} 
policy and an endogenously determined premium value on foreign exchange, an optimal setting of the exchange rate can provide the optimal trade intervention. Under a freely floating exchange rate any departure from this optimal rate will typically inflict welfare losses. In a two country model, a retaliatory exchange rate game, related to well known tariff games can be constructed, for which a Nash equilibrium in exchange rates can be computed.

We present the model, and illustrate possible outcomes using numerical simulation, and discuss its relevance to the contemporary Chinese situation where services are unliberalized and tariffs are bound in the WTO. We would not pretend that this model realistically captures all of the relevant features of the financial and real sides of the Chinese economy, and hence may only be suggestive in its implications for current policy. Importantly, there is no foreign exchange premium in China since China is currently running a trade surplus rather than the balanced trade our model specifies, and concerns over potential capital flight under a free float are the most important factor in current debates and they are not captured here. But the implication that if services remain largely unliberalized (as in China today) and tariff rates are bound in the WTO a move to a free float may be welfare worsening in our analysis seems both clear and relevant, and should be kept in mind by those currently advocating a free Renminbi float.

\section{A Model of Spatial and Inter-Temporal Trade with a Fixed Exchange Rate and Non-Neutral Monetary Policy}

We consider a world in which two types of trade are possible. One is inter-spatial trade between countries in commodities, and the other inter-temporal trade facilitated by providers of intermediation services. To simplify things, we further assume that intermediation services, when they are provided, are supplied at zero cost to users of services, and also that such services can only be provided by foreign service providers. This gross simplification implies that all intertemporal trade implies international trade in intermediation services, but adopting it means that we can consider autarky in services to be a case where no intertemporal intermediation occurs, and free trade in services to be the case where full inter-temporal intermediation occurs. If services remain unliberalized budget constraints within each period hold when we consider changes in exogenous variable (such as fixed exchange rates) in the model. We do not claim that this is a realistic representation of how service sectors operate in actual economies, but it is a useful analytical simplification.

We assume a fixed exchange rate regime with resulting monetary non-neutralities. We assume domestic currency is needed to execute domestic transactions while foreign currency is both needed for purchases of imports and yielded by the sale of exports. We only consider the transaction demand for money and in our formulation all foreign exchange earnings of exporters are surrendered to the central bank at the fixed exchange rate, while foreign exchange received by the bank is auctioned among importers at a premium to the official exchange rate. This premium value is endogenously determined given monetary policy, and operates akin to a tariff. (Also see Clarete and Whalley [5]).

For simplicity, we consider the 2 period $(t=0,1), 1$ country, 2 good $(l=1,2)$ pure exchange international trade case of a small open price taking economy. Adding additional features such as production, or more periods or goods, merely complicates the analysis while the themes remain the same.

The model can be presented as follows. The country has a single representative consumer, with endowments of the two goods in each period ( $E_{l}^{t} ; t=0,1, l=1,2$ ), and inter-temporal preferences written as

$$
\begin{aligned}
U & =\sum_{t=0}^{1} \frac{1}{(1+\rho)^{t}} u^{t}\left(X_{1}^{t}, X_{2}^{t}\right) \\
& =u^{0}\left(X_{1}^{0}, X_{2}^{0}\right)+\frac{1}{1+\rho} u^{1}\left(X_{1}^{1}, X_{2}^{1}\right)
\end{aligned}
$$

where $\rho$ is inter-temporal discount factor and $X_{l}^{t}$ denotes consumption of good $l$ at date $t$.

If a time-additive Cobb-Douglas utility function of the form $u^{t}\left(X_{1}^{t}, X_{2}^{t}\right)=\left[X_{1}^{t}\right]^{\alpha_{1}^{t}}\left[X_{2}^{t}\right]^{\alpha_{2}^{t}}$ for $t=0,1$ is used, (1) can be represented more explicitly as

$$
U=\left[X_{1}^{0}\right]^{\alpha_{1}^{0}}\left[X_{2}^{0}\right]^{\alpha_{2}^{0}}+\frac{1}{1+\rho}\left[X_{1}^{1}\right]^{\alpha_{1}^{1}}\left[X_{2}^{1}\right]^{\alpha_{2}^{1}}
$$

where $\alpha_{l}^{t}$ is the share parameter for good $l$ at date $t$ $\left(\sum_{l=1}^{2} \alpha_{l}^{t}=1\right)$. We can also consider CES preferences.

For good $l$ in each period $t$, the exogenous world price is $\Pi_{l}^{t}$. We allow the country to impose tariffs at rate $T_{l}^{t}$ on each imported good $l$ (i.e. if $X_{l}^{t} \geq E_{l}^{t}$, then $T_{l}^{t} \geq 0$ ). Tariffs are set to equal zero if good $l$ is exported (i.e. if $X_{l}^{t} \leq E_{l}^{t}$, then $T_{l}^{t}=0$ ). Internal (gross of tariff) prices for good $l$ at date $t$ are thus

$$
P_{l}^{t}=\Pi_{l}^{t}\left(1+T_{l}^{t}\right), \quad t=0,1, \quad l=1,2 .
$$

These are also sellers prices of good $l$.

Tariff revenues collected in period $t$ are

$$
R^{t}=\sum_{l=1}^{2} \Pi_{l}^{t} T_{l}^{t}\left(X_{l}^{t}-E_{l}^{t}\right)^{+}, \quad t=0,1
$$

where $E_{l}^{t}$ denotes the initial endowment of good $l$. Income in period $t$ is given by

$$
I^{t}=\sum_{l=1}^{2} P_{l}^{t} E_{l}^{t}+R^{t}, \quad t=0,1 .
$$


We consider the case in which both goods are traded, and there is both a fixed exchange rate and rationed foreign exchange. We assume that the government fixes the exchange rate at $e^{t}$, and requires all foreign exchange earned by exporters to be surrendered to the Central Bank at the rate $e^{t}$. It then allocates rights to purchase available foreign exchange to importers at the same rate $e^{t}$. We will assume that exporters comply with this policy and fully meet the surrender requirement, even though there are obvious incentives for exporters to conceal foreign exchange and attempt to sell it on parallel (black) markets rather than surrender it at the lower fixed rate. The allocation process of foreign exchange among importers assumes that the government auctions (or sells) foreign exchange. In practice, allocation schemes actually followed are more complex than this involving priority allocation of various forms, but we abstract from these. But under such a simple auctioning scheme, if desired imports require more foreign exchange than the government offers for sale, the price of foreign exchange paid by importers will be bid up. This price will thus include a foreign exchange premium above the fixed rate $e^{t}$, which we designate as $\lambda^{t}$. This premium acts as a surcharge on foreign exchange bought by importers, and adjusts so as to clear the foreign exchange market.

In this formulation the net effect of foreign exchange rationing is similar to a tariff on all imports, since the exchange rate received by exporters differs from the gross of premium value exchange rate paid by importers. The difference from a tariff is that the premium rate (or tariff equivalent rate) is endogenously determined. Also, under an auctioning scheme, the foreign exchange premium accrues to the government, but if rights to purchase foreign exchange at the rate $e^{t}$ were instead allocated by the government without charge, the premium would instead go directly to importers.

The world prices for the 2 goods are given as $\Pi_{l}^{t}$ for $t=0,1$ and $l=1,2$. Domestic prices (gross of tariff and gross of the foreign exchange premium for imports) for the 2 goods are again denoted as $P_{l}^{t}$ for $t=0,1$ and $l=$ 1,2 , and are defined below by (7).

Assuming unitary velocity of circulation and that the only demand for money is for transaction purposes, the demand for domestic currency $M_{D}^{t}$ at date $t$ is given by the value of domestic demands in domestic currency, i.e.

$$
M_{D}^{t}=\sum_{l=1}^{2} P_{l}^{t} X_{l}^{t}, \quad t=0,1
$$

Implicitly, we assume that imports are bought by middle men (imports) using foreign currency, who then import costlessly and sell imports at domestic prices. The supply of domestic currency at date $t$ is assumed to be set by the domestic monetary authorities and is given by $M_{S}^{t}$.

Because of the foreign exchange premium, relative do- mestic prices of the 2 traded goods will now differ from world prices both due to the premium on foreign exchange and the tariff, depending upon whether the good is imported or exported. Domestic prices $P_{l}^{t}$ gross of the foreign exchange premium are thus now given by

$$
P_{l}^{t}= \begin{cases}e^{t} \Pi_{l}^{t}, & \text { if } X_{l}^{t}-W_{l}^{t} \leq 0 \\ \left(1+\lambda^{t}\right) e^{t} \Pi_{l}^{t}, & \text { if } X_{l}^{t}-W_{l}^{t}>0\end{cases}
$$

where $X_{l}^{t}-W_{l}^{t}$ denotes the net import of goods $l$, and $\lambda^{t}$ is the premium value over the official exchange rate paid by purchasers of imports.

The demand for foreign currency $N_{D}^{t}$ at date $t$ is given by the value of imports at world prices

$$
N_{D}^{t}=\sum_{l=1}^{2} \Pi_{l}^{t}\left[X_{l}^{t}-W_{l}^{t}\right]^{+}, \quad t=0,1 .
$$

The supply of foreign currency $N_{S}^{t}$ at date $t$ is given by the value of exports at world prices

$$
N_{S}^{t}=\sum_{l=1}^{2} \Pi_{l}^{t}\left[X_{l}^{t}-W_{l}^{t}\right]^{-}, \quad t=0,1 .
$$

We consider two types of equilibrium. One of these is characterized by no provision of intermediation services by foreign services providers, and since we assume them to be the only potential service providers, no inter-temporal intermediation. In this equilibrium, period by period budget constraints apply for the economy, and we associate such an equilibrium with autarky in services trade. The other type of equilibrium is characterized by costless international flows of intermediation services (or free trade in services), and in this case combined period by period budget constraints hold. The only role for foreign services providers in the model is to costlessly facilitate intermediation within the price taking economy.

If there is no trade in intermediation services trade balance holds in each period, which implies that the value of imports goods is equal to the value of export and hence $N_{D}^{t}=N_{S}^{t}$ for $t=0,1$. Trade balance implies that

$$
\sum_{l=1}^{2} \Pi_{l}^{t}\left[X_{l}^{t}-W_{l}^{t}\right]=0 .
$$

which also implies that total revenues accruing to sellers of rights to purchase foreign exchange at the rate $e^{t}$ are

$$
R^{t}=\lambda^{t} e^{t} \sum_{l=1}^{2} \Pi_{l}^{t}\left[X_{l}^{t}-W_{l}^{t}\right]^{+}, \quad t=0,1
$$

These revenues accrue either directly to the household sector as additional income of importers who are given allocations of foreign exchange by the government which they resell on premium markets, or indirectly as recycled government revenues. Because anticipated revenues $L^{t}$ from rights of access to foreign exchange affect commodity demands and are a component of income for at least one of 
the agents in the model, market demand functions have to be rewritten to reflect this. Both $L^{t}$ and $R^{t}$ are each endogenously determined, and $L^{t}=R^{t}$ only in equilibrium.

The budget constraint for the household sector in this case includes initial holdings of money balances, and is given by

$$
I^{t}=\sum_{l=1}^{2} P_{l}^{t} W_{l}^{t}+M_{S}^{t}+L^{t}, \quad t=0,1
$$

\subsection{General Equilibrium with Service Trade Autarky (Period by Period Budget Constraints)}

When there is service trade autarky no intermediation services are provided since by assumption there are no domestic service providers ${ }^{2}$. This means that there is incompleteness in the coverage of markets in the sense that in service trade autarky intertemporal markets are missing. This enables us to appeal directly to literature on multicommodity inter-temporal models of incomplete markets due to Radner [10], Hart [11], Duffie and Shafer [12], Werner [13], Duffie [14], Geanakopolos [15], Magill and Shafer [16], and Magill and Quinzii [17] in analyzing the effects of service liberalization in this model. In services trade autarky there is no inter-temporal trade, while with costless inter-temporal trade in services inter-temporal markets are complete. We use incomplete markets literature without the added complication of uncertainty; most of this literature is concerned with existence issues; our focus here is comparative statics.

In the absence of trade in financial intermediation services the total value of expenditures must satisfy the household budget constraint in each period, i.e.,

$$
\sum_{l=1}^{2} P_{l}^{t} X_{l}^{t}+M_{D}^{t}=I^{t}, \quad t=0,1
$$

that is,

$$
\sum_{l=1}^{2} P_{l}^{t} X_{l}^{t}+M_{D}^{t}=\sum_{l=1}^{2} P_{l}^{t} W_{l}^{t}+M_{S}^{t}+L^{t}, \quad t=0,1
$$

or

$$
\begin{aligned}
& e^{t} \sum_{l=1}^{2} \Pi_{l}^{t}\left[X_{l}^{t}-W_{l}^{t}\right]+\left(M_{D}^{t}-M_{S}^{t}\right)+\left(R^{t}-L^{t}\right)=0, \\
& t=0,1
\end{aligned}
$$

A single country equilibrium in this case is given by values of $\left(\lambda^{t}, L^{t}\right)$ which satisfy the conditions:

1) $\left(X_{l}^{t}: t=0,1 ; l=1,2\right)$ solves

$$
\begin{aligned}
& \max U \\
& \text { s.t. } \sum_{l=1}^{2} P_{l}^{t} X_{l}^{t}+M_{D}^{t}=\sum_{l=1}^{2} P_{l}^{t} W_{l}^{t}+M_{S}^{t}+L^{t}, \quad t=0,1
\end{aligned}
$$

${ }^{2}$ See the discussion of barriers to trade in intermediation services in practice in Chen and Schembri [6], Francois and Schuknecht [7], Kalirajan, McHuire, Nguyen and Schuele [8], and Mattoo [9].
2) For $t=0,1$, trade balance, premium revenue balance, and money demand and supply equalities hold in each period.

$$
\begin{aligned}
& e^{t} \sum_{l=1}^{2} \Pi_{l}^{t}\left[X_{l}^{t}-W_{l}^{t}\right]=0 \text { and } \\
& R^{t}-L^{t}=0 \text { and } M_{D}^{t}-M_{S}^{t}=0
\end{aligned}
$$

2) Implies that $N_{D}^{t}=N_{S}^{t}$ for $t=0,1$.

\subsection{General Equilibrium with Free Trade in Services (Across Period Budget Constraints)}

If costlessly provided foreign supplied intermediation services are allowed in the model, then we can characterize a free trade in services equilibrium as a case where across period budget constraints hold rather than period by period budget constraints. In this model form, we assume the interest rate $r$ is endogenously determined on the country capital market to clear demand for and supply of loans. The economy is then only a price taker in goods markets, and foreign financial intermediaries only provide their services to the single country.

In this case, the demand for foreign currency is $N_{D}=\sum_{t=0}^{1} \frac{N_{D}^{t}}{(1+r)^{t}}$. The supply of foreign currency is $N_{S}=\sum_{t=0}^{1} \frac{N_{S}^{t}}{(1+r)^{t}}$. Trade balance now implies that the value of imports equals the value of exports and $N_{D}=N_{S}$, i.e.

$$
\begin{aligned}
& \sum_{t=0}^{1} \frac{1}{(1+r)^{t}} \sum_{l=1}^{2} \Pi_{l}^{t}\left[X_{l}^{t}-W_{l}^{t}\right] \\
= & \sum_{l=1}^{2} \Pi_{l}^{0}\left[X_{l}^{0}-W_{l}^{0}\right]+\frac{1}{1+r} \sum_{l=1}^{2} \Pi_{l}^{1}\left[X_{l}^{1}-W_{l}^{1}\right]=0 .
\end{aligned}
$$

With trading now allowed across the 2 periods under liberalized trade in financial intermediation services, the total value of expenditures satisfy the household budget constraint in each period, including borrowing and lending across periods, i.e.,

$$
\left\{\begin{array}{l}
\sum_{l=1}^{2} P_{l}^{0} X_{l}^{0}+M_{D}^{0}+F=I^{0} \\
\sum_{l=1}^{2} P_{l}^{1} X_{l}^{1}+M_{D}^{1}=I^{1}+(1+r) F
\end{array}\right.
$$

where following the literature on incomplete markets $F$ is the amount of credit extended across periods by foreign finance service providers. (19) can be rewritten as

$$
\left\{\begin{array}{l}
\sum_{l=1}^{2} P_{l}^{0} X_{l}^{0}+M_{D}^{0}+F=\sum_{l=1}^{2} P_{l}^{0} W_{l}^{0}+M_{S}^{0}+L^{0} \\
\sum_{l=1}^{2} P_{l}^{1} X_{l}^{1}+M_{D}^{1}=\sum_{l=1}^{2} P_{l}^{1} W_{l}^{1}+M_{S}^{1}+L^{1}+(1+r) F
\end{array}\right.
$$


or

$$
\left\{\begin{array}{l}
e^{0} \sum_{l=1}^{2} \Pi_{l}^{0}\left[X_{l}^{0}-W_{l}^{0}\right]+\left(M_{D}^{0}-M_{S}^{0}\right)+\left(R^{0}-L^{0}\right)+F=0 \\
e^{1} \sum_{l=1}^{2} \Pi_{l}^{1}\left[X_{l}^{1}-W_{l}^{1}\right]+\left(M_{D}^{1}-M_{S}^{1}\right)+\left(R^{1}-L^{1}\right)=(1+r) F
\end{array}\right.
$$

or

$$
\begin{aligned}
& e^{0} \sum_{l=1}^{2} \Pi_{l}^{0}\left[X_{l}^{0}-W_{l}^{0}\right]+\frac{1}{1+r} e^{1} \sum_{l=1}^{2} \Pi_{l}^{1}\left[X_{l}^{1}-W_{l}^{1}\right] \\
& +\left(M_{D}-M_{S}\right)+(R-L)=0
\end{aligned}
$$

where $M_{D}=M_{D}^{0}+\frac{1}{1+r} M_{D}^{1}$ is the value of demands in present value terms for domestic currency, $M_{S}=M_{S}^{0}+\frac{1}{1+r} M_{S}^{1}$ is the value of supply in present value terms for domestic currency, $R=R^{0}+\frac{1}{1+r} R^{1}$ are the revenues across periods accruing to sellers of rights to purchase foreign exchange, and $L=L^{0}+\frac{1}{1+r} L^{1}$ are anticipated revenues across periods distributed to consumers from auctioned foreign exchange.

A simple country equilibrium in this case is given by values of $\left(\lambda^{t}, L^{t}, F, r\right)$ which satisfy the conditions:

1) $\left(X_{l}^{t}: t=0,1 ; l=1,2\right)$ solve

$$
\begin{aligned}
& m \max U \\
& \text { s.t. } \sum_{l=1}^{2} P_{l}^{0} X_{l}^{0}+M_{D}^{0}+F=\sum_{l=1}^{2} P_{l}^{0} W_{l}^{0}+M_{S}^{0}+L^{0} \\
& \sum_{l=1}^{2} P_{l}^{1} X_{l}^{1}+M_{D}^{1}=\sum_{l=1}^{2} P_{l}^{1} W_{l}^{1}+M_{S}^{1}+L^{1}+(1+r) F
\end{aligned}
$$

and 2)

$$
\begin{aligned}
& \sum_{t=0}^{1} \frac{1}{(1+r)^{t}} e^{t} \sum_{l=1}^{2} \Pi_{l}^{t}\left[X_{l}^{t}-W_{l}^{t}\right]=0, R-L=0 \text { and } \\
& M_{D}^{t}-M_{S}^{t}=0 \text { for } t=0,1
\end{aligned}
$$

2) In this case implies

$\sum_{t=0}^{1} \frac{1}{(1+r)^{t}} N_{D}^{t}=\sum_{t=0}^{1} \frac{1}{(1+r)^{t}} N_{S}^{t}$. In this model, goods flows and intermediation services interact as follows. With liberalized service flows there is intertemporal intermediation and more specialization in consumption by period and hence more international trade. For given monetary policy and a given fixed exchange rate, liberalized service flows result in a higher value of and hence more severely distorted goods trade internationally. If alternatively, the fixed exchange rate is raised, then there is less distortion of trade but the unliberalized service trade implies that gains from intertemporal intermediation go unrealized. The first best policy combination is for liberalized services trade and a floating exchange rate. But if services trade remains unliberalized there is an optimal trade intervention even for a small open economy. In the case where period by period budget constraints apply, there will be an optimal trade intervention and, for given monetary policy, an optimal exchange rate. If instead across period budget constraints apply (with free trade in services) there will be no optimal exchange rate. The implication is that if tariffs are bound under WTO/GATT and services remain unliberalized (as in China) either monetary or exchange rate policy provide instruments for achieving the optimal trade intervention. If monetary policy is given, an optimal exchange rate will exist, and any departure from this via a free float will impose welfare losses. The possibility of such outcomes in the model can be explored by numerical simulation in which fixed exchange rates are parametrically varied.

\section{Some Numerical Simulation Results Indicating an Optimal Exchange Rate}

We have used numerical simulation to explore whether in the presence of given monetary policy (money supply fixed in each period), bound tariffs on goods traded internationally (assumed to be zero), and service trade remaining unliberalized there can be an optimal exchange rate. Depending on where any given exchange rate is relative to the optimal exchange rate,losses or gains can occur with a move to a free float. If the initial fixed exchange rate is by chance equal to the optimal exchange rate, losses must necessarily occur.

The size of the effects involved depend critically on the numerical example chosen, and in Table 1 we provide a sample parameterization for a model with Cobb Douglus in which the combination of fixed exchange rates and domestic money supply imply lpremium values on foreign exchange and hence distortion of goods trade, we also consider a case with different preferences across periods, so that gains from intertemporal intermediation will also occur. To simplify, world prices are unity, as are fixed exchange rate.

We have used the structure set out in Section 2 to perform some numerical simulations for a simple economy which show how in the presence of given monetary policy (in the form of a setting of the money supply), WTO bound tariffs on goods flows, and service trade remaining unliberalized, there will be an optimal exchange rate. In such cases depending on the setting of the fixed exchange rate, welfare losses may occur with any move to a freely floating exchange rate, raising questions as to the desirability of a free Renminbi float in China. Losses will necessarily occur if the fixed exchange rate equals its optimal value. 
Table 1. Parameters values used in 1 country 2 period 2 good numerical simulation exploration of optimal exchange rates.

\subsection{Model Characteristics}

- Small Open Price Taking Economy

- 1 Country 2 Period 2 Good

- Cobb Douglas Utility Functions within the Period

1.2. Model Parameterization

- Utility Inter-Temporal Discount Rate

$$
\rho=0.10
$$

- Share Parameter in Preferences

$$
\begin{array}{ll}
\alpha_{1}^{0}=0.50 & \alpha_{2}^{0}=0.50 \\
\alpha_{1}^{1}=0.60 & \alpha_{2}^{1}=0.40
\end{array}
$$

- Initial Endowments

$$
\begin{array}{ll}
W_{1}^{0}=20 & W_{2}^{0}=80 \\
W_{1}^{1}=25 & W_{2}^{1}=75
\end{array}
$$

- World Prices

$$
\begin{array}{ll}
\Pi_{1}^{0}=1.00 & \Pi_{2}^{0}=1.00 \\
\Pi_{1}^{1}=1.00 & \Pi_{2}^{1}=1.00
\end{array}
$$

- Initial Fixed Exchange Rate in Each Period

$$
e^{0}=e^{1}=1.50
$$

- Domestic Money Supply in Each Period

$$
M_{S}^{0}=160 \text { and } M_{S}^{1}=200
$$

In the simulations we perform, we assume for simplicity Cobb-Douglas preferences and consider a case where period by period budget constraints apply reflecting unliberalized services trade. The model parameter settings we use in our simulations are given in Table 1. For this parametrization, we take monetary policy as given and then compute equilibrium solutions for alternative settings of the exchange rate to explore the behaviour of the optimal exchange rate. Table 2 presents an equilibrium solution for this model, given the exchange rate and monetary policy in Table 1.

For the case where no trading is allowed across periods $F=0$, and the equilibrium is given in the first column of Table 2 (the model parametrization set out in Table 1). In this case when such trading is allowed, the foreign exchange premium value is the same in both periods and equals 0.413 . Utility increases from 94.641 to 95.125. Imports equals exports in each period and fall from 26.66 to 17.47 in period 0 and increase from 21.66 to 31.62 in period 1 . Transactions across the period include borrowing and lending of 13.379 .

Table 3 reports the optimal exchange rate for this model parameterization, along with the welfare impacts which would follow with a move to a freely floating exchange rate under which the premium value on foreign exchange is eliminated. Utility reaches its maximal value of 96.3851 when the common exchange rate $e^{0}=e^{1}=1.770$ is used in both periods. If, instead the exchange rate is only varied in period 0 , a similar utility gain occurs and utility
Table 2. General equilibrium for the model parameterization set out in Table 1.

\begin{tabular}{cc}
$\begin{array}{c}\text { Period by Period Budget } \\
\text { Constraints }\end{array}$ & $\begin{array}{c}\text { Across Period Budget } \\
\text { Constraints }\end{array}$ \\
& \multicolumn{1}{c}{ Interest Rate } \\
Exchange Rate Premium Value \\
$\lambda^{0}=0.143$ and $\lambda^{1}=0.714 \quad$ Domestic Prices & $\lambda^{0}=\lambda^{1}=0.413$ \\
& \\
$P_{1}^{0}=1.714$ & $P_{1}^{0}=2.119$ \\
$P_{2}^{0}=1.500$ & $P_{2}^{0}=1.500$ \\
$P_{1}^{1}=2.571$ & $P_{1}^{1}=2.119$ \\
$P_{2}^{1}=1.500$ & $P_{2}^{1}=1.500$
\end{tabular}

Utility Levels in Each Period, and Across Periods

$$
\begin{aligned}
& U^{0}=49.889 \quad U^{0}=44.868 \\
& U^{1}=49.227 \quad U^{1}=55.282 \\
& U=94.641 \quad U=95.125 \\
& X_{1}^{0}=46.667 \quad X_{1}^{0}=37.747 \\
& X_{2}^{0}=53.333 \quad X_{2}^{0}=53.333 \\
& X_{1}^{1}=46.667 \quad X_{1}^{1}=56.621 \\
& X_{2}^{1}=53.333 \quad X_{2}^{1}=53.333 \\
& H_{1}^{0}=26.667 \quad H_{1}^{0}=17.747 \\
& H_{1}^{1}=21.667 \quad H_{1}^{1}=31.621 \\
& H_{2}^{0}=26.667 \quad H_{2}^{0}=26.667 \\
& H_{2}^{1}=21.667 \quad H_{2}^{1}=21.667
\end{aligned}
$$

Foreign Currency Demand

$$
\begin{aligned}
& N_{D}^{0}=26.667 \quad N_{D}^{0}=17.747 \\
& N_{D}^{1}=21.667 \quad N_{D}^{1}=31.621 \\
& N_{D}=46.081 \\
& \text { Foreign Currency Supply } \\
& \begin{array}{ll}
N_{S}^{0}=26.667 & N_{S}^{0}=26.667 \\
N_{S}^{1}=21.667 & N_{S}^{1}=21.667 \\
& N_{S}=46.081
\end{array}
\end{aligned}
$$

Foreign Exchange Premium Revenues in Each Period

$$
\begin{aligned}
R^{0}=5.714 & R^{0}=10.992 \\
R^{1}=23.214 & R^{1}=19.585 \\
R & =28.541
\end{aligned}
$$

Income in Each Period

$$
\begin{array}{lrl}
I^{0}=320.000 & I^{0}=333.379 \\
I^{1}=400.000 & & I^{1}=385.069 \\
& \text { Money Deposit } & \\
F=0.000 & F & =13.379
\end{array}
$$


across the two periods is 96.207. In this case the loss is relative small, but this nonetheless establishes the presumption in favour of a fixed over a floating exchange rate in this case when the rate is varied across both periods. Table 3 reports a utility loss relative to the optimal exchange rate in both periods when a freely floating exchange rate occurs.

Table 4 reports the relationship between utility and domestic money supply changes, since changed monetary policy provides a substitute instrument for exchange rate policy in this model. Utility reaches its maximal value of 96.418 when the money supply $M_{S}^{0}$ in period 0 equals 112.000. Results in Table $\mathbf{4}$ also show the utility loss relative to optimal monetary policy when monetary policy is used to eliminate the foreign exchange premium. In this case once again the difference is relatively small, but clearly present.

A difference between Tables $\mathbf{3}$ and $\mathbf{4}$ is the impact on results of only allowing optimal policy interventions in one period. In the case of exchange rate policy, optimal intervention generates welfare effects which are smaller than those under a free float, and only with optimal common exchange rates across the two periods is the gain larger than that under free float. In contrast, the gain from optimal monetary policy only in period 1 exceeds that from optimal policy across the two periods. These outcomes reflect both direct gains from additional intermediation across time and the indirect effects between trade in goods

Table 3. Maximum utility under an optimal exchanges rate (across period budget constraint equilibria in all cases).

\begin{tabular}{|c|c|c|c|}
\hline Base Case & $\begin{array}{c}\text { Optimal Exchange } \\
\text { Rate }\end{array}$ & Free Float & $\begin{array}{c}\text { Optimal Exchange } \\
\text { Rate }\end{array}$ \\
\hline \multirow[t]{4}{*}{ Equilibrium } & Equilibrium & Equilibrium & Equilibrium \\
\hline & $\begin{array}{c}\text { (Same Exchange } \\
\text { Rate }\end{array}$ & $\begin{array}{c}\text { (Same Exchange } \\
\text { Rate }\end{array}$ & (Changing Only \\
\hline & Both Periods) & Both Periods) & $\begin{array}{l}\text { Exchange Rate in } \\
\text { Period 1) }\end{array}$ \\
\hline & \multicolumn{2}{|c|}{ 3.1. Domestic Monetary Supply } & \\
\hline$M_{S}^{0}=160$ & $M_{S}^{0}=160$ & $M_{S}^{0}=160$ & $M_{S}^{0}=160$ \\
\hline$M_{S}^{1}=200$ & $M_{S}^{1}=200$ & $M_{S}^{1}=200$ & $M_{S}^{1}=200$ \\
\hline \multicolumn{4}{|c|}{ 3.2. Exchange Rate } \\
\hline$e^{0}=1.500$ & $e^{0}=1.770$ & $e^{0}=1.792$ & $e^{0}=1.5000$ \\
\hline$e^{1}=1.500$ & $e^{1}=1.770$ & $e^{1}=1.792$ & $e^{1}=1.7857$ \\
\hline \multicolumn{4}{|c|}{ 3.3. Exchange Rate Premium Value } \\
\hline$\lambda^{0}=0.413$ & $\lambda^{0}=0.023$ & $\lambda^{0}=0.000$ & $\lambda^{0}=0.1783$ \\
\hline$\lambda^{1}=0.413$ & $\lambda^{1}=0.023$ & $\lambda^{1}=0.000$ & $\lambda^{1}=0.1783$ \\
\hline \multicolumn{4}{|c|}{ 3.4. Utility Across Periods } \\
\hline 95.125 & 96.385 & 96.379 & 96.207 \\
\hline
\end{tabular}

Table 4. Maximum utility under an optimal monetary policy (across period budget constraint equilibria in all cases).

\begin{tabular}{|c|c|c|c|}
\hline \multirow{2}{*}{ Base Case } & \multicolumn{2}{|c|}{ Optimal Monetary Optimal Monetary } & \multirow{2}{*}{ Monetary Policy } \\
\hline & Policy & Policy & \\
\hline Equilibrium & in Period 0 & in Both Periods & $\begin{array}{l}\text { Set So as to } \\
\text { Eliminate }\end{array}$ \\
\hline & & & $\begin{array}{l}\text { Foreign Exchange } \\
\text { Premium }\end{array}$ \\
\hline \multicolumn{4}{|c|}{ 4.1. Domestic Monetary Supply } \\
\hline$M_{S}^{0}=160$ & $M_{S}^{0}=112.000$ & $M_{S}^{0}=135.560$ & $M_{S}^{0}=103.621$ \\
\hline$M_{s}^{1}=200$ & $M_{s}^{1}=200.000$ & $M_{S}^{1}=169.450$ & $M_{S}^{1}=200.000$ \\
\hline \multicolumn{4}{|c|}{ 4.2. Exchange Rate } \\
\hline$e^{0}=1.500$ & $e^{0}=1.500$ & $e^{0}=1.500$ & $e^{0}=1.500$ \\
\hline$e^{1}=1.500$ & $e^{1}=1.500$ & $e^{1}=1.500$ & $e^{1}=1.500$ \\
\hline \multicolumn{4}{|c|}{ 4.3. Exchange Rate Premium Value } \\
\hline$\lambda^{0}=0.413$ & $\lambda^{0}=0.051$ & $\lambda^{0}=0.0225$ & $\lambda^{0}=0.000$ \\
\hline$\lambda^{1}=0.413$ & $\lambda^{1}=0.051$ & $\lambda^{1}=0.0225$ & $\lambda^{1}=0.000$ \\
\hline \multicolumn{4}{|c|}{ 4.4. Utility across Periods } \\
\hline 95.125 & 96.418 & 96.385 & 96.379 \\
\hline
\end{tabular}

and over time, and which one dominates varies from case to case.

These results thus suggest that a fixed exchange rate can dominate a floating rate if monetary policy is not available as the instrument to achieve the optimal trade intervention.

\section{Conclusions}

This paper presents a model of international trade with both inter-temporal and inter-spatial trade motivatedly by current debate on both Renminbi revaluation and a possible Renminbi free float in China. In this model if intertemporal trade is restricted by service regulation and tariff rates are bound in the WTO, even for a small open price taking economy free trade in goods will typically not be the best policy. A fixed exchange rate policy with a surrender requirement on exporters and rationing (or auctioning) of foreign exchange among importers can be a welfare improving intervention compared to a free floating exchange rate. This analysis seems relevant to the present debate in China where services unliberalized until the terms of China's WTO accession fully apply and tariff rates are bound under China's WTO accession terms.

While this analysis may not be fully realistic of the situation in economies such as China under international pressure to liberalize their exchange rate regime, it provides possible intellectual coherence to a position that best policy may not be to move to a free float prior to full financial services liberalization. In China, unlike in our analysis, there is no foreign exchange premium and China runs a trade surplus in goods trade. However, to the extend that concerns over possible capital flight motivate the maintainence of the present exchange rate regime which 
limits convertability, the broad themes of the analysis still seem relevant. The policy implications thus run counter to accepted international conventional wisdom and point to possible advantages of not freely floating.

\section{REFERENCES}

[1] M. Friedman, "Essays in Positive Economics," Chapter on the Case for Flex Exchange Rate, 1956.

[2] Z. Pan and F. Zhang, "Determination of China's LongRun Nominal Exchange Rate and Official Intervention," China Economic Review, Vol. 15, No. 3, 2004, pp. 360365. doi:10.1016/j.chieco.2004.04.002

[3] G. Chang and Q. Shao, "How Much Is the Chinese Currency Undervalued? A Quantitative Estimation,” China Economic Review, Vol. 15, No. 3, 2004, pp. 366-371.

[4] H. Huang, J. Whalley and S. Zhang, "Trade Liberalization in a Joint Spatial Inter-Temporal Trade Model,” Research Paper, The University of Western Ontario, 2004.

[5] R. Clarete and J. Whalley, "Foreign Exchange Premia and Non-Neutrality of Monetary Policy in General Equilibrium Models,” Journal of International Economics, Vol. 30, No. 1-2, 1991, pp. 153-166.

[6] Z. Chen and L. Schembri, "Measuring the Barriers to Trade in Services: Literature and Methodologies," In: J. M. Curtis and D. C. Ciuriak, Eds., Trade Policy Research, Development of Foreign Affairs and International Trade, 2002.

[7] J. Francois and L. Schuknecht, "International Trade in Financial Services, Competition and Growth Performance," Centre for International Economic Studies, No. 6, 2000.

[8] K. Kalirajan, G. McHuire, D. Nguyen-Hong and M. Schuele, "The Price Impact of Restrictions on Banking Services,” In: C. Findlay and T. Warren, Eds., Impediments to trade in Services: Measurement and Policy Im- plications, Routledge, New York, 2001.

[9] A. Mattoo, "Financial Services and the WTO: Liberalization Commitments of the Developing and Transition Economies,” Policy Research Working Paper No. 2184, Developing Research Group, World Bank, Washington DC, 1999.

[10] R. Radner, "Existence of Equilibrium of Plans, Prices and Price Expectations in a Sequence of Markets," Econometrica, Vol. 40, No. 2, 1972, pp. 289-303. doi:10.2307/1909407

[11] O. D. Hart, "On the Optimality of Equilibrium When the Market Structure Is Incomplete," Journal of Economic Theory, Vol. 11, No. 3, 1975, pp. 418-443. doi:10.1016/0022-0531(75)90028-9

[12] D. Duffie and W. Shafer, "Equilibrium in Incomplete Markets: I: A Basic Model of Generic Existence,” Journal of Mathematical Economics, Vol. 14, No. 3, 1985, pp. 285-300.

[13] J. Werner, "Equilibrium in Economies with Incomplete Financial Markets,” Journal of Economic Theory, Vol. 36, No. 1,1985 , pp. 110-119. doi:10.1016/0022-0531(85)90081-X

[14] D. Duffie, "Stochastic Equilibria with Incomplete Financial Markets,” Journal of Economic Theory, Vol. 41, No. 2, 1987, pp. 405-416.

[15] J. D. Geanakoplos, "An Introduction to General Equilibrium with Incomplete Asset Markets,” Journal of Mathematical Economics, Vol. 19, No. 1-2, 1990, pp. 1-38. doi:10.1016/0304-4068(90)90034-7

[16] M. Magill and W. Shafer, "Incomplete Markets," In: W. Hildenbrand and H. Sonnenschein, Eds., Handbook of Mathematical Economics, Vol. 4, Elsevier Science, New York, 1991, pp. 1523-1614.

[17] M. Magill and M. Quinzii, “Theory of Incomplete Markets,” MIT Press, Cambridge, 1996. 